\title{
オホーツク海のズワイガニ漁獲物の 令期組成について
}

菅野 泰 次

(1974 年 12 月 23 日受理)

\section{On the Method of Estimation of Age Composition of Male Tanner Crabs in the Okhotsk Sea}

\author{
Yasuji KANNo*
}

To examine the method of estimation of age composition of the tanner crab, Chionoecetes opilio, the frequency distribution of the carapace width was analized, basing on an assumption that the variation of the carapace of a single moulting age is subject to a normal distribution.

In samples collected in the south Saghalien area in 1971, the frequency distribution of the carapace width ranged from $80 \mathrm{~mm}$ to $140 \mathrm{~mm}$ or more these were divided into 5 basic size groups to represent succesive moulting ages, the mean for each group being $85 \mathrm{~mm}, 98 \mathrm{~mm}, 112 \mathrm{~mm}, 124 \mathrm{~mm}$ and $134 \mathrm{~mm}$ and the standard deviations of $3.3 \sim 5.6 \mathrm{~mm}$.

Application of the 5 normal distributions described as the formula $\mathrm{F}(x)=\sum a_{i} \phi_{i}(x)$ to the commercial catch carght in east Saghalien area in 1970 showed high comformity between observed and calculated frequencies.

From the above results, it seems that a method for the estimation of age composition is available for practical use, when adequate estimates of growth in relation to moulting age can be obtained with accuracy in the future by experimental studies.

Growth of the carapace width regarding moulting ages fits the logistic equation, $l_{t}=152 / 1+e^{2.31-0.899 t}$.

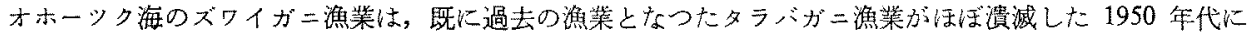
始められたものである。この海域のズワイガニに関する資源生物学的な知見は土門等, ${ }^{1 \sim 3)}$ 高橋, によつて若千報告されてはいるが，年令組成の解析は，ズワイガニが年令形質をむたないためにまだ手がつ けられていない。

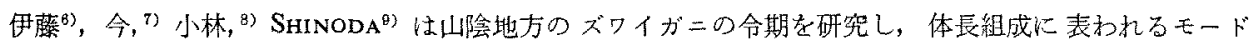
の位着からそれそれれの命期と体長との関媇を求めたが，高令群では体長の重複する部分が大きいため分離が 困難で，必ずしる報告結果が一致していない。また才ホーック海の漁獲物の甲幅組成を描いても，その分布 型は年度や漁獲地点によつて矩型的分布，多峰型むるいは左右に歪んだ単峰分布を示すなど一定せず，単純 に命期意決定し難いところがある。

分布型がこのよらに不規則かつ多様な型を示すのは，これらが要菜となるいくつかの基碟的分布から搆成 され，種々の割合で合成されているためであると考党られる。本報告はこの考充に基づき，甲輻 $80 \mathrm{~mm}$ 以 上のズワイガ二漁蒦物の甲幅組成に5つの正規分布を仮定し，これらから合成される分布が一般の漁獲物の 分布と適合するかどうかを調へ，年令組成解析への手がかりを得よらとした。

* 北海道立網走水産試默場 (Hokkaido Abashiri Fisheries Experimental Station, Abashiri, Japan) 
本文に入るに先立ち，甲幅長の测定資料の使用を許された網走水産試験場黑島和夫氏，および原稿の校閲 を晹つた浜井生三博士に対して深く感謝申し上げる。

\section{方法}

い变一年令群の体長分布が正規分布をするものと仮定して、いくつかの年令群が混合する場合を考える と，そ机らは混合の此率と個体変異の大きさによつて，さまざまの割合で重なり合らから，そのヒストグラ ムは結果の Fig. 2 見るよらな波状曲線を形つくるであろう。この正規型体長群の混合組成の累積百分率 を正規確率紙に描くと，組成により特異な曲線觉形ら゙くるから HARDING, ${ }^{10)} \mathrm{CASSIE}^{11)}$ の方法に従つて適 切に分割することにより，むとの要素となる正規分布を分離することが出来る。この時の正規分布のバラ 一ターである平均值 $\mu$ と標準编差 $\sigma$ は正規確率紙上の直線を読むことにより求められる。このようにして, それぞれの正規分布の平均値と標準偏差が知られると，混合組成に淤るるる体長階級 $(x)$ の度数は下式 （1）により決定されるから，逆に観察される実度数 F(x) を知ることにより，要素となる正規分布の大きさ $a_{i}$ を算出することが出来る。

$$
\mathrm{F}(x)=\sum a_{i} \phi_{i}(x)
$$

ここで $\mathrm{F}(x)$ 注体長階級 $(x)$ に含恋机る度数, $a_{i}$ は $i$ 年令群の個体数, $\phi_{i}(x)$ は $i$ 年令群の個体の体長 階級 $(x)$ に拉计る確率密度関数である。

確率紙を用いて求められた体長組成上（1）式から計算された体長組成沈，ともに理論度数と観察実度数 を $x^{2}$ 一法により検定して，想定された理論の適合の良さを調べることが出来る。

材料

用いた材料は 1971 年 5 9 月に, 樺太中知床岬沖の水深約 $200 \mathrm{~m}$ のズワイガ二漁場で漁獲され，筆者 によつて測定された資料と，この解折結果を応用した第 2 の資料からなる。第 2 の資料は 1970 年 4 9 月 に樺太東岸の北綽 45 51 度の大陸棚上で漁獲されたるので，解折は緯度別に分離して取り扱学れている。 また报われた材料はすべて雄がニで漁具は籠網である。漁獲物からの標本抽出は無作為抽出を原則としたが， 第 2 の資料の中には大小の型別分けられた後の標本斗若干含まれている。

結

果

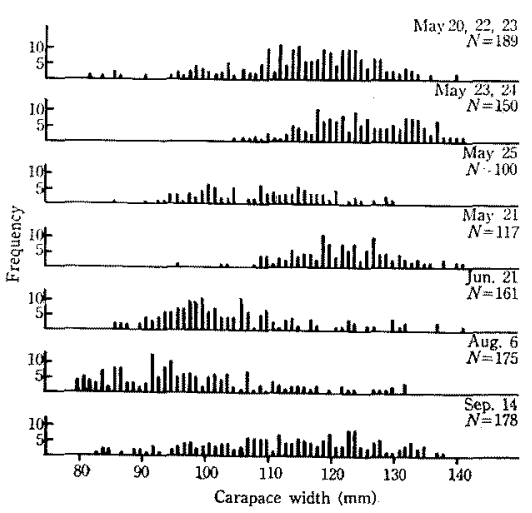

Fig. 1. Frequency distribution of carapace width of 7 samples of tanner crab caught by crab trap fishing boats on south Saghalien area in 1971.
要素となる 5 つの正規体長群の分離 1971 年に測定 した 7 個のサンプルの甲幅頻度分布を Fig. 1 亿示す。サ ンブルKよつて分布図に表われるモードの位置はそれでれ 異なるが，近接するものを統合すると，全体をつらぬくモ 一ドの位置は扰よそ $85 \sim 87 \mathrm{~mm}, 95 \sim 100 \mathrm{~mm}, 110 \sim 113$ $\mathrm{mm}, 123 \sim 124 \mathrm{~mm}, 130 \sim 137 \mathrm{~mm}$ の 5 つと見ることがで きる。

上述の7 個のサンプルを合計した甲幅頻度分布を Fig. 2 に示す。测定誤差扰よび読みとりのくせによる偏りを除く ために， 3 点移動平均を用いてある。1070 個体の分布か らは多峰型，それも 4 峰を見ることができる。この分布の 累積度数を求め, そのパーセンテージを正規確率紙に描く と Fig. 3 の曲線となる。これを CASSIE の方法に従つて 属曲点を境に5つの部分に分け，それぞれの部分に正規分 布を仮定すると，平行する5 本の直線に分離される (Fig. 3)。 それぞれの直楾の平均值と摽準偏羑を図から読みとると 


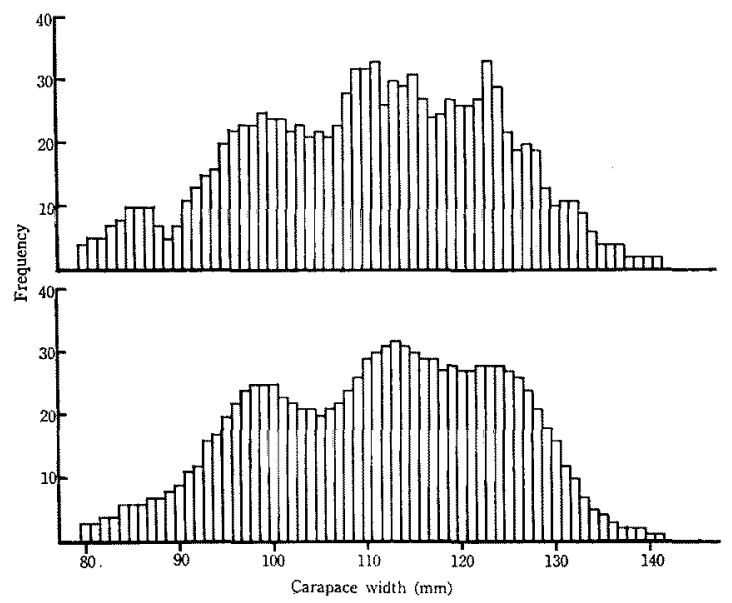

Fig. 2. Comparison of total frequency distribution (above) in which 7 samples shown in Fig. 1 were combined together, with theoretical frequency distribution by using normal probability graph method (below).

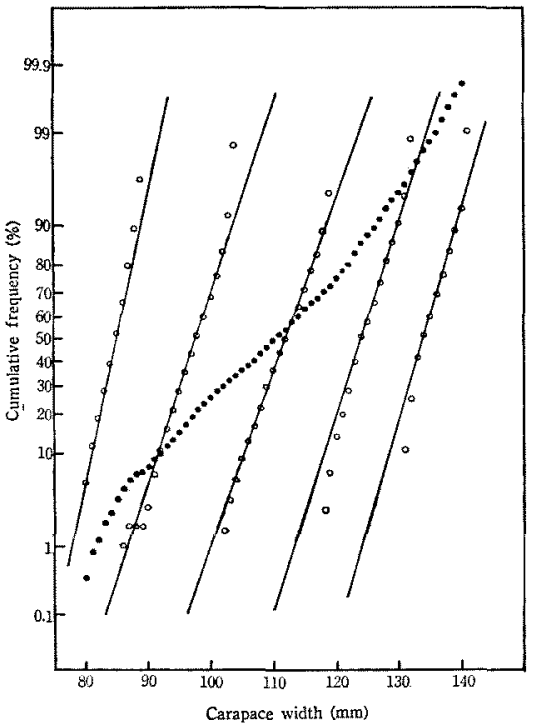

Fig. 3. Cumulative percentage frequency distribution in carapace width of 1070 tanner crabs caught on south Saghalien area in 1971.
Table 1. Estimated means and standard deviations of 5 length groups extracted from normal probability graph

\begin{tabular}{ccc}
\hline \hline $\begin{array}{c}\text { Length } \\
\text { group }\left(a_{i}\right)\end{array}$ & $\begin{array}{c}\text { Mean } \\
(\mathrm{mm})\end{array}$ & $\begin{array}{c}\text { Standard } \\
\text { deviation }(\mathrm{mm})(\sigma)\end{array}$ \\
\hline 1 & 85 & 3.3 \\
2 & 98 & 4.8 \\
3 & 112 & 5.6 \\
4 & 124 & 4.7 \\
5 & 134 & 4.3 \\
\hline
\end{tabular}

Table 1 となる。すなわち平均値は $85,98,112,124$, $134 \mathrm{~mm}$ 火あり，標準偏差は 3.3 5.6 mm の間にあ る。 $85 \mathrm{~mm}$ に平均値をもつ第 1 群の $\sigma$ の值が他汇較 ベて小さいが，これは $80 \mathrm{~mm}$ 以下の個体を計算から 除外したためと，小さい個体ほど漁獲時選択的に投 率される率が高いことによる。確率紙によつて分けら れたそれぞれの体長群の大きさから，5つの正規分布 の度数を求め，それを合成して $x^{2}$-検定により観察度 数との適合度を調べると， $x^{2}=28.59$ 亿d. $\mathrm{f}=39,(\mathrm{P}>$ $0.75\}$ となり，良い適合を示すことが認められた。 要素となる正規分布の一般漁獲物甲幅組成への応用 1970 年の漁獲物から抽出された 2,404 個体の甲 幅頻度分布を漁場別（緯度別）に描くとFig. 4 となる(この場合にも3 点移動平均をとつた）。相隣る体長群 のオーハーラッブの程度が大きく，しかも中位の度数が高いために，それぞれの分布は単峰を形成し，いく つの体長群から構成されているかを着取することは難しい。この各甲幅に占める度数は，前述した5つの体 長群が正規型確率密度関数 $\phi(x)$ K従5分布をすると仮定し，それぞれの甲幅に対する 5 体長群の $\phi(x)$, 
各体長群の実度数 $\mathrm{F}(x)$ とから，5つの要素体長群のそれぞれの個体数 $\left(a_{i}\right)$ を次の連立方程式を解くこと に上つて求めた (Table 2)。

$$
\begin{aligned}
& \phi_{11} a_{1}+\phi_{21} a_{2}+\phi_{91} a_{3}+\phi_{41} a_{4}+\phi_{51} a_{5}-F_{1}=0 \\
& \phi_{12} a_{1}+\phi_{22} a_{2}+\phi_{82} a_{3}+\phi_{42} a_{4}+\phi_{52} a_{5}-F_{2}=0 \\
& \phi_{13} a_{1}+\phi_{28} a_{2}+\phi_{38} a_{3}+\phi_{43} a_{4}+\phi_{53} a_{5}-F_{3}=0 \\
& \phi_{14} a_{1}+\phi_{24} a_{2}+\phi_{34} a_{3}+\phi_{44} a_{4}+\phi_{54} a_{5}-F_{4}=0 \\
& \phi_{18} a_{1}+\phi_{25} a_{2}+\phi_{36} a_{3}+\phi_{45} a_{4}+\phi_{55} a_{5}-F_{5}=0
\end{aligned}
$$

計算は密度関数 $\phi_{i j}$ を要素とする 5 次の行列式を解いて求めた。この時の $\sigma$ の值はすべて $5 \mathrm{~mm}$ とし， 甲幅籍囲は計算の簡単のために $80 \sim 92 \mathrm{~mm}, 93 \sim 105 \mathrm{~mm}, 106 \sim 118 \mathrm{~mm}, 119 \sim 129 \mathrm{~mm}, 130 \mathrm{~mm}$ 以上の 5 区分とした (Table 3)。

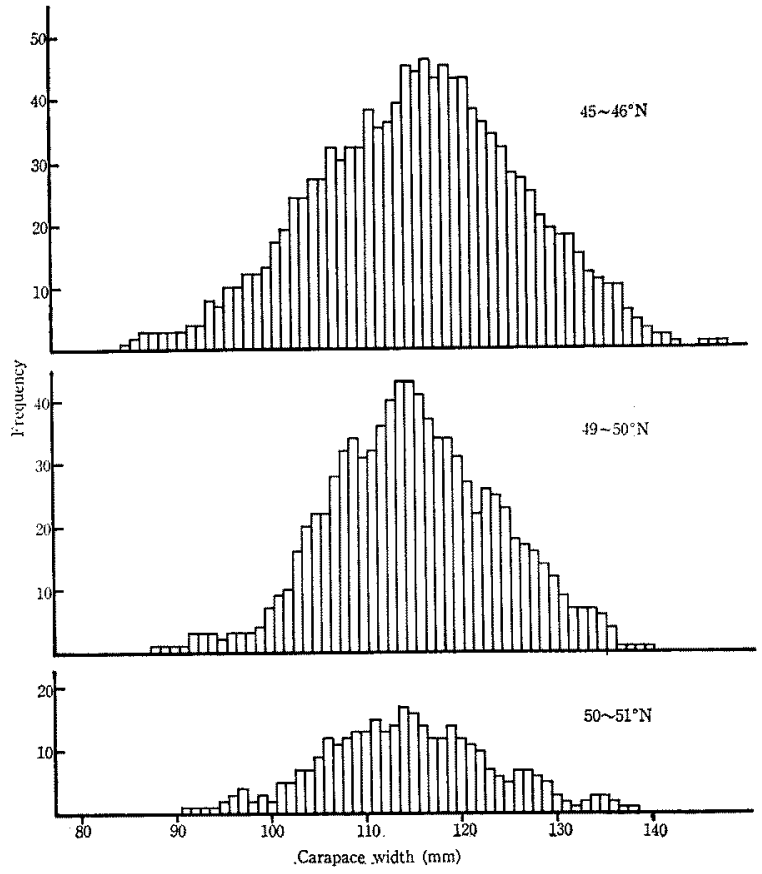

Fig. 4. Frequency distribution of carapace width in the tanner crab caught by commercial fishing on east Saghalien area, divided into 3 latitudinal ranges, in 1970.

\begin{tabular}{|c|c|c|c|c|c|c|}
\hline Sample/F(x) & $80 \sim 92$ & $93 \sim 105$ & $106 \sim 118$ & $119 \sim 129$ & $130 \sim$ & Total \\
\hline 1971 & 102 & 280 & 361 & 261 & 66 & 1070 \\
\hline $45^{\circ} \sim 46^{\circ} \mathrm{N}$ & 22 & 188 & 479 & 372 & 134 & 1195 \\
\hline $1970\left\{49^{\circ} \sim 50^{\circ} \mathrm{N}\right.$ & 7 & 105 & 453 & 253 & 56 & 874 \\
\hline $50^{\circ} \sim 51^{\circ} \mathrm{N}$ & 2 & 51 & 174 & 90 & 18 & 335 \\
\hline
\end{tabular}

Table 2. Individual numbers $\mathrm{F}(x)$ observed in 5 carapace width intervals, in which 1971 year's sample caught in south Saghalien is used for analysis of probability graph method and 1970 year's samples caught in east Saghalien are applied to the formula $\mathrm{F}(x)=\sum a_{i} \phi_{i}(x)$ 
求められた体長群の個体数 $a_{i}$ から計算甲幅度数を求め, 観察甲幅度数との適合度の検定結果を Table 4 に示した。結果はすべてのサンブルに良い適合を示すとはいるないことを示している。ここで計算甲幅度数

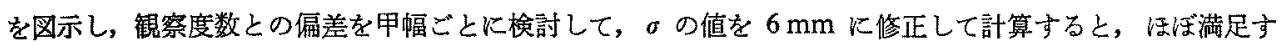

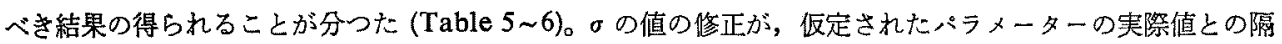
たりを意味するものか，単なる測定の精粗を，あるいは体長群の年度的・地域的変異を示すものかを今明ら かにすることは出来ないが，適切な值の推定によつて，高い適合度を得ることができれば，後に諭議される 精度の範囲内で，令期組成を推定する実用泩を示唆していると考えられよう。

Table 3. Numerical composition of 5 length groups calculated by using the formula $F(x)=\sum a_{i} \phi_{i}(x)$

\begin{tabular}{lrrlrrr}
\hline \multicolumn{1}{c}{ Sample $/ a_{i}$} & 1 & 2 & 3 & 4 & 5 & Total \\
\hline 1971 & 59 & 315 & 379 & 314 & 3 & 1070 \\
$1970\left\{\begin{array}{c}45^{\circ} \sim 46^{\circ} \mathrm{N} \\
49^{\circ} \sim 50^{\circ} \mathrm{N}\end{array}\right.$ & 0 & 171 & 542 & 429 & 62 & 1204 \\
$50^{\circ} \sim 51^{\circ} \mathrm{N}$ & 0 & 51 & 565 & 254 & 6 & 876 \\
\hline
\end{tabular}

Table 4. $x^{2}$ test of goodness of fit between observed frequency distribution and calculated one by using the formula $\mathrm{F}(x)=\sum a_{i} \phi_{i}(x)$, assuming $5 \mathrm{~mm}$ standard deviation for 5 means of each group

\begin{tabular}{|c|c|c|c|}
\hline Sample & $x^{2}$ & d. $f$ & $\mathrm{p}$ \\
\hline 1971 & 45.68 & 37 & $>0.10$ \\
\hline $45^{\circ} \sim 46^{\circ} \mathrm{N}$ & 38.82 & 35 & $>0.25$ \\
\hline $1970,49^{\circ} \sim 50^{\circ} \mathrm{N}$ & 29.19 & 24 & $>0.20$ \\
\hline $50^{\circ} \sim 51^{\circ} \mathrm{N}$ & 11.25 & 20 & $>0.90$ \\
\hline
\end{tabular}

考察

1 年令群の体長組成を正規分布と見做して年令群を分離した研究はいくつかする。岡 ${ }^{18}$ はキダイについて 1 年令群の体長分布が 正規分布を描くことの理論的な根拠を述一， 李た田中, ${ }^{14,15)}$ 青山, ${ }^{182}$ 木下, ${ }^{17)}$ 須田, ${ }^{193}$ 浜井・石戸 ${ }^{19)}$ は体長組成に正規分布を仮定して年令群を分離し，その有効性を諭議した。筆者の研究では Fig. 2 に示したサンブルに执いて 5 つの甲幅群が分離され，理論度数と観察度数との良い適合が得られた。 ここで分離された甲幅群が真の命期群を示すかどうかについて疑点が残るので分離された各々の甲幅群の体 長差の原因を考えれぱ，それ脱皮回数の違い基づく成長差を示すか，あるいは同し脱皮回数でも成長度 に暹いがあることに帰着する。後者はさらに，生理的に異つた成長度を示す異質な群の混合と，捿息環境を 異にするための成長度の違いに分離できようが，隣り合う体長群のモードの間隔が 10 15 mm，つまり同令 期の变埋と見るには大きすぎること牦せ，この間隔が5つの体長群を通じてほぼ一定であることを考える ならば，後者つまり成長度の違いを原因と見ることには無理があり，令期の違い比基づく体長差と考光てよ いと思われる。

この值を他の研究によつて推測された值と較べるために,データを HIATT の定差図にのせ，式を計算する と $l_{n+1}=0.916 l_{n}+21.007$ となる。この式の $l_{n}$ の倸数の值は相隣る令期汇拈ける体镸の增加分の比 $\left(\Delta l_{n+1} /\right.$

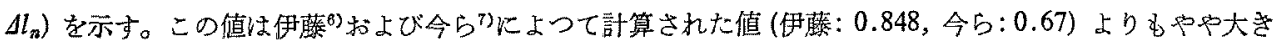
く, 高令のカ二の脱皮成長が筆者の得た結果の方が高いことを示している。けれどるここに用いられた値は 三者ともに，体長組成のモードの位䈯か:らの推定值によつているので，実成長度之の誤差については標識放 流試験あるいは飼育試験による実験的なデータによつて確証する必要がある。 
Table 5. Comparison of observed frequencies with theoretical ones calculated by the formula $F(x)=\sum a_{i} \phi_{i}(x)$, when the fixed 5 means and $6 \mathrm{~mm}$ standard deviations were given. Samples were caught in east Saghalien in 1970

\begin{tabular}{|c|c|c|c|c|c|c|}
\hline \multirow{2}{*}{$\begin{array}{l}\text { Carapace } \\
\text { width }\end{array}$} & \multicolumn{2}{|c|}{$45^{\circ} \sim 46^{\circ} \mathrm{N}$} & \multicolumn{2}{|c|}{$49^{\circ} \sim 50^{\circ} \mathrm{N}$} & \multicolumn{2}{|c|}{$50^{\circ} \sim 51^{\circ} \mathrm{N}$} \\
\hline & observed & calculated & observed & calculated & observed & calculated \\
\hline 82 & & & & & & \\
\hline 3 & 0 & 0 & & & & \\
\hline 4 & 0 & 0 & & & & \\
\hline 5 & 1 & 1 & & & & \\
\hline 6 & 2 & 2 & 0 & 1 & & \\
\hline 7 & 3 & 2 & 0 & 1 & & \\
\hline 8 & 3 & 2 & 1 & 1 & 0 & 1 \\
\hline 9 & 3 & 4 & 1 & 2 & 0 & 1 \\
\hline 90 & 3 & 5 & 1 & 2 & 0 & 1 \\
\hline 1 & 3 & 5 & 1 & 2 & 1 & 1 \\
\hline 2 & 4 & 7 & 3 & 3 & 1 & 2 \\
\hline 3 & 4 & 8 & 3 & 3 & 1 & 2 \\
\hline 4 & 8 & 9 & 3 & 4 & 1 & 2 \\
\hline 5 & 7 & 11 & 2 & 5 & 2 & 3 \\
\hline 6 & 10 & 12 & 3 & 6 & 3 & 3 \\
\hline 7 & 10 & 12 & 3 & 6 & 4 & 3 \\
\hline 8 & 12 & 14 & 3 & 7 & 2 & 4 \\
\hline 9 & 12 & 15 & 4 & 8 & 3 & 4 \\
\hline 100 & 13 & 15 & 7 & 9 & 2 & 4 \\
\hline 1 & 17 & 17 & 9 & 11 & 5 & 5 \\
\hline 2 & 19 & 17 & 10 & 11 & 5 & 5 \\
\hline 3 & 24 & 19 & 16 & 14 & 7 & 6 \\
\hline 4 & 24 & 21 & 20 & 16 & 7 & 7 \\
\hline 5 & 27 & 22 & 22 & 18 & 9 & 7 \\
\hline 6 & 27 & 25 & 22 & 22 & 12 & 9 \\
\hline 7 & 32 & 28 & 28 & 25 & 11 & 10 \\
\hline 8 & 30 & 29 & 32 & 27 & 12 & 11 \\
\hline 9 & 32 & 33 & 34 & 32 & 13 & 12 \\
\hline 110 & 32 & 36 & 31 & 34 & 13 & 13 \\
\hline 1 & 38 & 36 & 32 & 34 & 15 & 13 \\
\hline 2 & 35 & 39 & 36 & 37 & 13 & 14 \\
\hline 3 & 36 & 40 & 40 & 38 & 14 & 15 \\
\hline 4 & 39 & 38 & 43 & 36 & 17 & 14 \\
\hline 5 & 45 & 41 & 43 & 38 & 16 & 14 \\
\hline 6 & 44 & 41 & 41 & 37 & 14 & 14 \\
\hline 7 & 46 & 37 & 37 & 32 & 12 & 12 \\
\hline 8 & 43 & 38 & 34 & 33 & 12 & 12 \\
\hline 9 & 45 & 38 & 34 & 31 & 14 & 12 \\
\hline 120 & 43 & 35 & 31 & 28 & 12 & 10 \\
\hline 1 & 43 & 37 & 27 & 28 & 11 & 10 \\
\hline 2 & 38 & 37 & 22 & 27 & 10 & 10 \\
\hline 3 & 36 & 33 & 26 & 23 & 7 & 8 \\
\hline 4 & 34 & 34 & 25 & 24 & 6 & 8 \\
\hline 5 & 32 & 32 & 23 & 21 & 5 & 7 \\
\hline 6 & 28 & 30 & 18 & 19 & 7 & 7 \\
\hline 7 & 27 & 29 & 17 & 18 & 7 & 6 \\
\hline 8 & 25 & 28 & 16 & 17 & 6 & 6 \\
\hline
\end{tabular}


Table 5. Continued

\begin{tabular}{|c|c|c|c|c|c|c|}
\hline \multirow{2}{*}{$\begin{array}{l}\text { Carapace } \\
\text { width }\end{array}$} & \multicolumn{2}{|c|}{$45^{\circ} \sim 46^{\circ} \mathrm{N}$} & \multicolumn{2}{|c|}{$49^{\circ} \sim 50^{\circ} \mathrm{N}$} & \multicolumn{2}{|c|}{$50^{\circ} \sim 51^{\circ} \mathrm{N}$} \\
\hline & observed & calculated & observed & calculated & observed & calculated \\
\hline 9 & 21 & 24 & 14 & 14 & 5 & 5 \\
\hline 130 & 19 & 22 & 12 & 12 & 3 & 4 \\
\hline 1 & 18 & 21 & 9 & 11 & 2 & 4 \\
\hline 2 & 18 & 17 & 7 & 9 & 1 & 3 \\
\hline 3 & 15 & 16 & 7 & 8 & 2 & 3 \\
\hline 4 & 12 & 14 & 7 & 6 & 3 & 2 \\
\hline 5 & 11 & 11 & 6 & 5 & 3 & 1 \\
\hline 6 & 10 & 10 & 4 & 4 & 2 & 1 \\
\hline 7 & 10 & 9 & 1 & 3 & 1 & 1 \\
\hline 8 & 6 & 7 & 1 & 2 & 1 & 1 \\
\hline 9 & 4 & 6 & 1 & 2 & 0 & 1 \\
\hline 140 & 3 & 5 & 1 & 1 & & \\
\hline 1 & 2 & 4 & 0 & 1 & & \\
\hline 2 & 2 & 3 & 0 & 1 & & \\
\hline 3 & 1 & 2 & & & & \\
\hline 4 & 0 & 2 & & & & \\
\hline 5 & 0 & 1 & & & & \\
\hline 6 & 1 & 1 & & & & \\
\hline 7 & 1 & 1 & & & & \\
\hline 8 & 1 & 0 & & & & \\
\hline 9 & & & & & & \\
\hline
\end{tabular}

Table 6. $x^{2}$ test of goodness of fit between observed frequency distribution and theoretical frequency distribution calculated by the formule $\mathrm{F}(x)=\sum a_{i} \phi_{i}(x)$, assuming the standard deviation to be the same $6 \mathrm{~mm}$ for 5 means of each group

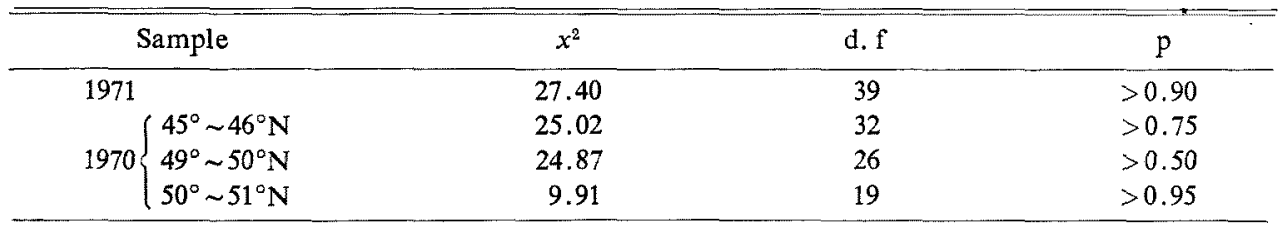

次に令期と成長との関係を知るために，脱皮間隔を単位時間 $(\Delta t)$ とした際の比成長率 $\left(l_{n+1}-l_{n} / l_{n} \cdot \Delta t\right)$ の 変化を Fig. 5 に示した。因には 4 10 命のデータについては伊藤のの推定值をとり，これに連なるるの として 11 令以降の推定值に筆者の結果をあてた。比成镸率の変化は体長に比例して減少する一次式で表わ され， ロジスチックの曲線 $\left(l_{t}=\mathrm{K} / 1+e^{a-r t}\right)$ がよく適合することを示している。この图からKとの値を 求め, 甲幅 $9.5 \mathrm{~mm}$ (4 令) を初期值とした際の $a$ の值を $a=\log _{e}\left(\mathrm{~K} / l_{0}-1\right)$ によてて定めると曲線式は $l_{t}=152 / 1+e^{2.31-0.308 t}$ となる。この式から第 5 令期以後の甲幅を計算し観察值と比較するとはば一致するこ とが認められる (Table 7, Fig. 6)。SHINODA ${ }^{\theta)}$ は甲幅 $42 \mathrm{~mm}$ 以上の令期と成長との関係を, 伊藤( 10 令 (甲幅 $60 \mathrm{~mm}$ ) 以降の令期と成長との関係を, それぞれ VON BERTALANFFY の成長式にのせて計算 している。しかし今ら゙および伊藤礼よつて導かれた HIATT の定差図によれば, 若令期と高令期では成 長が異なり，雄では中幅 $60 \mathrm{~mm}$ を境に $l_{n}$ の係数が前期では1より大，後期では 1 より小を示すことが知 られている。このことは，生淮の令期と成長との関係を BERTALANFFY の成長式のみで表現することが不 可能なことを意味しており，この点で，令期と成長との関係式ではロジスチックの式の利点が見られる。こ 
こに扱つた脱皮ごとの成長ではなく，1 年を単位とした年令と成長に関する式を求める場合にはどちらの 成長式がより適合するかまだ明らかでなく，今後の研究で険討されなけれぱならない。

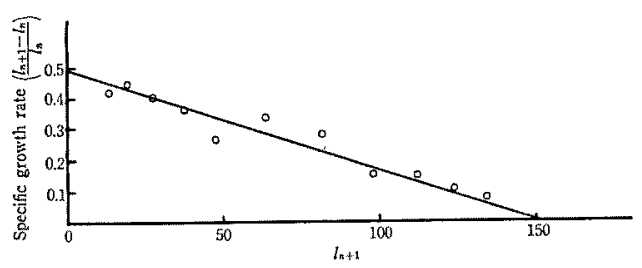

Fig. 5. Relation between specific growth rate $\left(\frac{l_{n+1}-l_{n}}{l_{n}}\right)$ and $l_{n+1}$ in the tanner crab, $l_{n}$ being the carapace width in moulting age $n$.

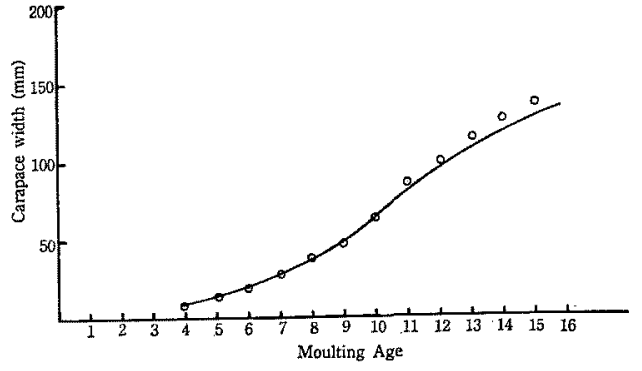

Fig. 6. Growth curve calculated by the logistic equation. Points show observed data.

Table 7. Comparison of carapace width calculated by the logistic equation with those observed

\begin{tabular}{|c|c|c|c|}
\hline \multirow{2}{*}{ Moult age } & \multicolumn{3}{|c|}{ Carapace width } \\
\hline & Calculated & Observed & \\
\hline 4 & $(9.5)$ & $9 \sim 10)$ & \multirow{12}{*}{ Ito $(1970)$} \\
\hline 5 & 13.7 & $13 \sim 14$ & \\
\hline 6 & 19.6 & $19 \sim 20$ & \\
\hline 7 & 27.5 & $27 \sim 28\}$ & \\
\hline 8 & 37.6 & $37 \sim 38$ & \\
\hline 9 & 49.9 & $47 \sim 48$ & \\
\hline 10 & 64.1 & $63 \sim 64)$ & \\
\hline 11 & 79.2 & 85 & \\
\hline 12 & 93.9 & 98 & \\
\hline 13 & 107.5 & 112 & \\
\hline 14 & 114.8 & 124 & \\
\hline 15 & 128.1 & 134 & \\
\hline
\end{tabular}

Table 8. Percentage of estimated errors basing on aberration from real value as to the mean and the standard deviation of a normal distribution

\begin{tabular}{ccccc}
\hline \multirow{2}{*}{ Standard deviation $(\mathrm{mm})$} & \multicolumn{5}{c}{ Aberration from mean $(\mathrm{mm})$} \\
\cline { 2 - 5 } & 1 & 2 & 3 & 4 \\
\hline 4 & 9.9 & 19.8 & $\%$ & 39.6 \\
5 & 7.9 & 15.8 & 29.7 & 26.8 \\
6 & 6.7 & 13.4 & 23.7 & 22.4 \\
\hline 7 & 5.6 & 11.2 & 16.8 & +2 \\
\hline
\end{tabular}


ズワイガニの単一令期群の体長組成が正規分布に近似できるものと見なして，パラメーターの推定值が実 際值から外れた時の，推定される令期組成の精度を比較してみた。言差(率)を実度数に対する誤坡度数の割 合と考えて，パラメーターの推定値が突際値からある隔たりをもつた時に導入される組成の䘫差を， $\mu$ と。 の実際值が推定値から外れた時の，同大の面積をむつ正規分布のずれとして計算した (Table 8)。表から， 平站値 $\mu$ で惟定值から $1 \mathrm{~mm}$ ずれるに従つて䄪 $6 \sim 10 \%$ の俱差が導入され，標準偏差では $\sigma=5$ から $1 \mathrm{~mm}$ ずれると 18 20\% の愦差が導入されることが知られる。さらに $2 \mathrm{~mm}$ ずれると標準偏差だけで 24 32\% の誤差となり，平均值の俱差と合わせると，実祭上実用に酎えないるのになる。仮に 70 80\%の

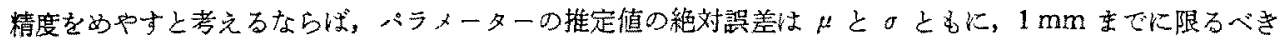
であうっ。

要 約

1971 年に南樺太海域で漁獲されたズワイガニ 1070 尾の測定值を解折して, $80 \sim 140 \mathrm{~mm}$ 余の閒に含末

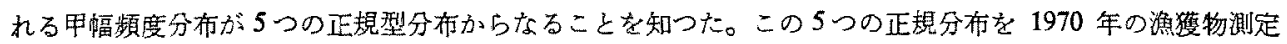
資料に広用して，計算甲幅組成上実測甲幅組成の適合度を調べると，若干のパラかーターの修正により良い 適合を示すことが知られた。この結果から，実駼による令期と体長との精度の高い推定値を得る研究老通し

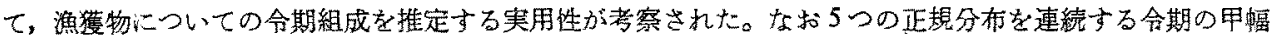
組成とすると，既存のデータを綜合した令期に対する甲幅の成長曲線はロジスチック曲線に適合すると推定 された。

\section{文献}

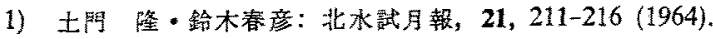

2) 土門 隆: 同誌, 23, 230-242 (1966).

3) 土阿 隆：ズワイガニ調查報告書, 北水研・北海道ズロイガ二漁势組, 1970, pp. 1 80.

4) 高楅 忠: 北水試月報, 26, 898-915 (1969).

5) 营野傣次: 北水陚報告, (14)，17-30 (1972).

6) 伊藤腾千代: 日水研恠，(22), 81-116 (1970).

7) 今 敒・丹羽正一・山川文男：本誌，34，138-142 (1968).

8）小林敏男：ズワイガニ調㚗報告書第 1 報, 兵庫県水試, 1966, pp. 1-68.

9) M. SHINODA: This Bull., 34, 185-190, (1968).

10) J. P. HaRding: J. Marine Biol. Ass. U. K., 28, 141-153, (1949).

11) R. M. CAssiz: Australian Jour. Marine Freshwater Res., 5, 513-522, (1954).

12）山中一郎：日水研業績策，(1)，109-117 (1954)。

13) 岡 正雄: 長崎大水産紀要, 2, 8-25 (1954).

14）田中晶一: 東海水研笮，(13)，35-50 (1956).

15) 田中昌一: 同誌, (14), 1-13 (1956).

16) 青山唒雄: 本䟤, 20, 677-680 (1954).

17）木下哲一郎：北大水産垈垠，20，25-35 (1969).

18) 須田 明：本誌，20，460-468 (1954).

19）浜井生三・石户芳男：東北水研知，(11)，1-37 (1958). 